\title{
Kirchenpaueria halecioides (Cnidaria: Hydrozoa): a non-native hydroid in the coast of Buenos Aires, Argentina
}

\author{
Gabriel Genzano* and Pablo E. Meretta
}

Estación Costera Nágera, Instituto de Investigaciones Marinas y Costeras (IIMyC), Universidad Nacional de Mar del Plata (UNMdP), Consejo Nacional de Investigaciones Científicas y Técnicas (CONICET), Argentina

Marine and

Fishery Sciences

MAFIS

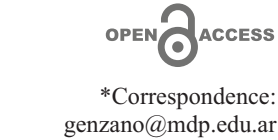

Received: 7 September 2020 Accepted: 27 October 2020

ISSN 2683-7595 (print) ISSN 2683-7951 (online)

https://ojs.inidep.edu.ar

Journal of the Instituto Nacional de Investigación y Desarrollo Pesquero (INIDEP)

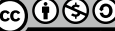

This work is licensed under a Creative Commons Attribution-

NonCommercial-ShareAlike 4.0 International License

\begin{abstract}
Hydroid colonies are among the groups frequently carried and introduced by human actions. Many species have been successfully transported as fouling organisms on ship hulls or in ballast water (pelagic stages) and the sea harbours appear as the places with high probability to detect exotic species. During routinely SCUBA diving conducted in Mar del Plata harbour, Argentina (38 $08^{\prime}$ S-57 $31^{\prime}$ W; May 2005, December 2006, March 2007, and December 2016) clumps of a plumularid were photographed and collected. Hydroid colonies were identified as Kirchenpaueria halecioides, a species frequently reported in tropical and subtropical water from the Southwestern Atlantic, Brazil. Records of mature colonies in 2006 and 2016 suggest local reproduction of this non-native species. Monitoring will be necessary in order to analyse if species colonize neighbouring areas or remain confined to the port area.
\end{abstract}

Key words: Exotic, harbour, early introduction, Southwestern Atlantic.

Kirchenpaueria halecioides (Cnidaria: Hydrozoa): un hidroide exótico en la costa de Buenos Aires, Argentina

RESUMEN. Las colonias de hidroides se encuentran entre los grupos transportados e introducidos frecuentemente por acciones humanas. Muchas especies han sido transportadas con éxito como organismos incrustantes en cascos de barcos o en agua de lastre (etapas pelágicas) y los puertos marítimos aparecen como los lugares con alta probabilidad de detectar especies exóticas. Durante el buceo rutinario realizado en el puerto de Mar del Plata, Argentina ( $38^{\circ} 08^{\prime} \mathrm{S}-57^{\circ} 31^{\prime} \mathrm{W}$; mayo 2005, diciembre 2006, marzo 2007 y diciembre 2016) se fotografiaron y recolectaron grupos de plumularidos. Las colonias de hidroides fueron identificadas como Kirchenpaueria halecioides, una especie frecuentemente reportada en aguas tropicales y subtropicales del Atlántico Suroeste, Brasil. Los registros de colonias maduras en 2006 y 2016 sugieren la reproducción local de esta especie no nativa. El monitoreo será necesario para analizar si las especies colonizan áreas vecinas o permanecen confinadas al área portuaria.

Palabras clave: Exótica, puerto, introducción temprana, Atlántico Sudoccidental.

Hydroids, the benthic stage of the hydrozoans, present different strategies for pelagic dispersion which include a planktonic sexual medusa (in species with metagenetic life cycle) and a free-swimming larva (usually a planula); but other dispersal strategies are present in the group which include dispersion by buoyant autotomised hydranths and tolerant or resistant stages 
(frustules) detached from colonies. Besides, colonies can live on rafting objects or as free-living fragments floating in the water column which provide another route for dispersal (Cornelius 1992, 1995; Bavestrello et al. 2000; Slobodov and Marfenin 2004; Jaubet and Genzano 2011). High growth rate, budding and the formation of stolons allow hydroids to colonize space rapidly and develop colonies on different types of substrates including living-organisms (Genzano et al. 2009).

Due to the mentioned characteristics, hydroid colonies are among the groups frequently transported and introduced to new habitats by human actions (Haydar 2012). Many species have been successfully carried as fouling organisms on ship hulls or in ballast water (pelagic stages) and the sea harbours appear as the places with high probability to detect exotic species. In addition, this environment can present greater hydrobiological stability in relation to external waters, favouring the feeding and growth of species.

Early detection of non-native species is a crucial first step in effective management and risk evaluation that these types of organisms can cause. Rapid response actions can reduce the long-term ecological harm that they could produce on communities.

During routinely SCUBA diving conducted in May 2005 in Mar del Plata harbour, Argentina $\left(38^{\circ} 08^{\prime} \mathrm{S}-57^{\circ} 31^{\prime} \mathrm{W}\right)$ a small patch of plumularid colonies were photographed, which was apparently different to that reported previously in the area (5 m depth, $14{ }^{\circ} \mathrm{C}$ ). During December 2006 SCUBA diving was conducted to collect these plumularid. Two matures and two immature colonies $\left(7 \mathrm{~m}\right.$ depth, $\left.18{ }^{\circ} \mathrm{C}\right)$ were detached from rocks and preserved in alcohol. Other clumps were photographed during March 2007 (5 m depth, $20.5^{\circ} \mathrm{C}$ ), and finally two mature colonies were collected $\left(5 \mathrm{~m}\right.$ depth, $\left.18.5^{\circ} \mathrm{C}\right)$ and preserved in alcohol in December 2016. Hydroid colonies were identified as Kirchenpaueria halecioides (Alder, 1859) (Hydrozoa, Kirchenpauriidae).
This species is easily recognized by the structure of the colony, the shape of the nematothecae and the barrel-shaped, corrugated gonothecae with a flattened top. Analysed colonies are erect, $10-20 \mathrm{~mm}$ high; the hydrocaulus is divided at regular intervals into internodes, each one bearing a distal nematotheca and a hydrocladial apophysis, alternate and bearing unbranched hydrocladia, divided at internodes. Thecate internodes with a distal hydrotheca, a median inferior nematotheca, and a median superior nematotheca. Hydrotheca cup-shaped, margin entire, central axis oblique to that of hydrocladium, with a circular aperture. Gonotheca is elongated oval, truncated at the distal end, with distinct transverse ridges arising by a short pedicel from hydrocaulus. These morphological characteristics are according to the previous description of this species (see Peña Cantero and García Carrascosa 2002) (Figure 1).

$K$. halecioides is a circum-tropical/temperate species with great tolerance to hydrological factors as salinity and temperature. Its wide distribution is probably influenced by its presence in sea harbours and regular occurrence as a fouling organism (Peña Cantero and García Carrascosa 2002, and references therein).

In the Southwestern Atlantic the species was found several times from shallow waters, rocky intertidal to $73 \mathrm{~m}$ depth, on algae, barnacles, mussels, hydroids, mud, mangle roots, rock, sandstone reef, shells and wood. All reports correspond to Brazil between $7.50^{\circ} \mathrm{S}$ to $8.50^{\circ} \mathrm{S}$, (tropical) and $20^{\circ} \mathrm{S}$ to $27.50^{\circ} \mathrm{S}$ (subtropical) waters (see Oliveira et al. 2016 for distribution and synonymies in these regions).

Thus, our findings represent the early introduction of $K$. halecioides in temperate water for the region, 1,160 miles southward to previous reports in South America.

Some colonies collected by us during December 2006 in Mar del Plata harbour (Genbank accession number haplotype \# 386) were recently examined by $16 \mathrm{~S}$ sequences by Moura et al. (2019), exhibiting the same haplotype with 


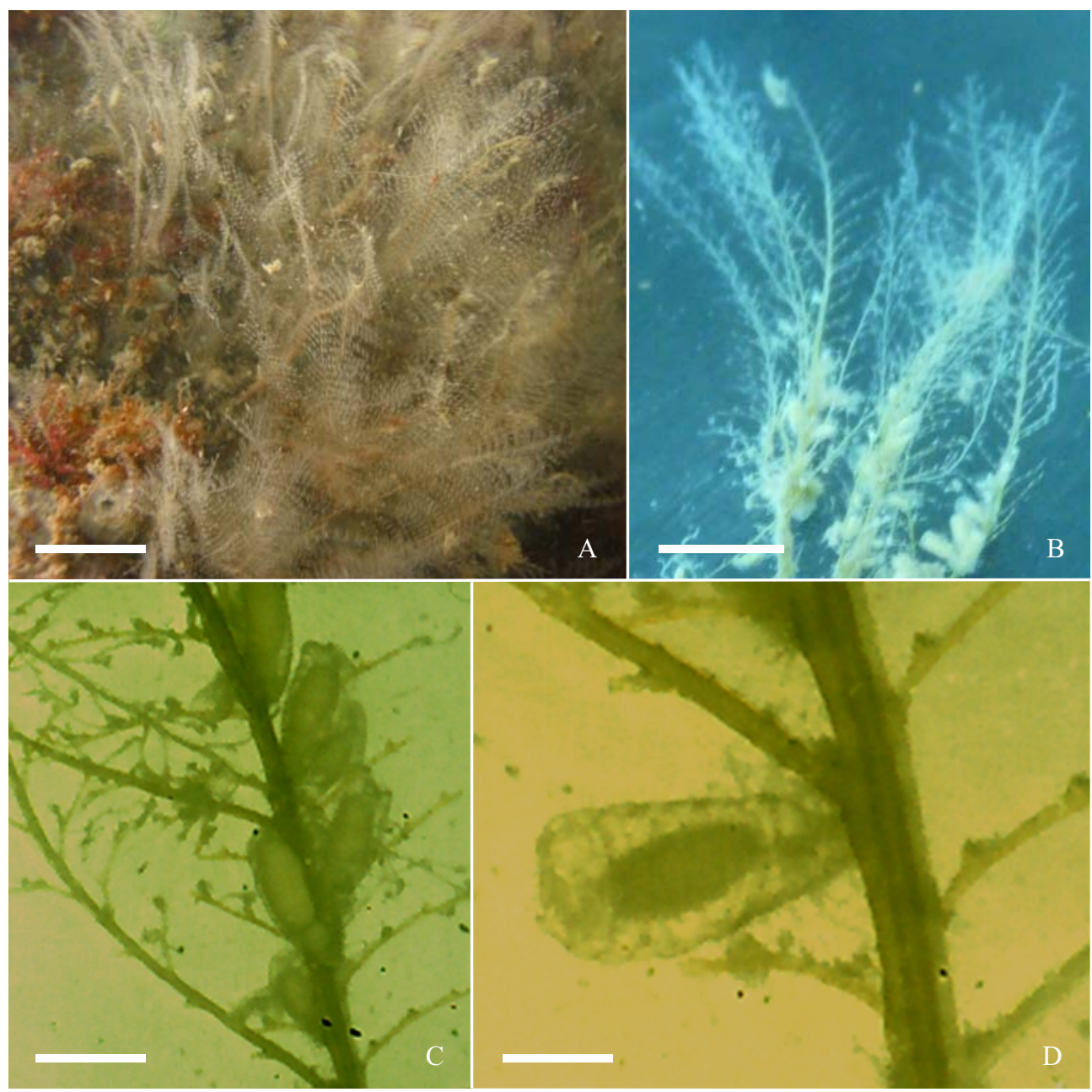

Figure 1. Kirchenpaueria halecioides. A and B) Colonies found in Mar del Plata harbour (scale $1 \mathrm{~cm}$ ). C and D) Detail of mature colonies and gonotheca (scale $0.25 \mathrm{~mm}$ ).

colonies collected in Madeira, Azores, and mainland Portugal, mostly in ports and marinas. Thus, we can infer that this taxon was dispersed through boats.

Detection of non-native species varies across regions and taxa. Hydroid faunal is well-studied in the coast of Buenos Aires, Argentina (Genzano et al. 2009). Particularly, in Mar del Plata harbour, SCUBA monitoring studies have been carried out by authors from the early ' 90 to the present; therefore, we can confirm that the record in
2005 could represent the starting point of an introduction of this hydroid in Argentina. The finding of the species does not imply successful colonization. However, subsequent records in 2006 and 2007 confirmed its presence in the area, and the finding of mature gonothecae in colonies in 2006 and 2016 suggested local reproduction.

Monitoring will be necessary to analyse changes in its abundance and detect if the species colonizes neighbouring areas or remain confined to the port area such as many other non-native species found in this particular habitat. 


\section{REFERENCES}

Bavestrello G, Puce S, Cerrano C, CastellaNo L, ARILlo A. 2000. Water movement activating fragmentation: a new dispersal strategy for hydractiniid hydroids. J Mar Biol Assoc UK. 80: 361-362.

Cornelius PFS. 1992. Medusa loss in leptolid Hydrozoan (Cnidaria) hydroid rafting, and abbreviated life-cycles among their remoteisland faunae: an interim review. In: BouILLON J, Boero F, Cicogna F, Gili JM, Hughes RG, editors. Aspects of hydrozoan biology. Sci Mar. 56 (2-3): 245-261.

CORNELIUS PFS. 1995. North-west European Thecate Hydroids and their Medusae (Cnidaria, Leptolida, Leptothecatae). Part 1. In: BARNES RSK, CROTHERS JH, editors. Linnean Society of London and The Estuarine and Coastal Sciences Association. 1-347.

Genzano GN, Giberto D, Schejter L, BremeC C, Meretta P. 2009. Hydroids assemblages in SW Atlantic (34-42 $\left.{ }^{\circ} \mathrm{S}\right)$ : richness and settlement substrata. Mar Ecol. 30 (1): 33-46.

HAYDAR D. 2012. What is natural? The scale of cryptogenesis in the North Atlantic Ocean. Divers Distrib. 18 (2): 101-110.
Jaubet L, Genzano GN. 2011. Seasonality and reproductive periods of the hydroid Clytia gracilis in temperate littoral ecosystems. Is asexual reproduction the prime mechanism in maintaining populations? Mar Biol Res. 7: 804-811.

Moura CJ, Collins AG, Santos RS, Lessios H. 2019. Predominant east to west colonizations across major oceanic barriers: Insights into the phylogeographic history of the hydroid superfamily Plumularioidea, suggested by a mitochondrial DNA barcoding marker. Ecol Evol. 9 (23): 13001-13016.

Oliveira OMP, Araujo EM, Ayón P, Cedeñoposso CM, Cepeda AA, Córdova P, Galea HR, Genzano GN, Haddad MA, Mianzan HW, et al. 2016. Census of the Cnidaria (Ceriantharia and Medusozoa) and Ctenophora from South American marine waters. Zootaxa. 4194 (1): 1-256.

Peña Cantero Al, García Carrascosa AM. 2002. The benthic hydroid fauna of the Chafarinas Islands (Alborán Sea, western Mediterranean). Zool Verh. 337: 1-180.

Slobodov SA, MARFENIN NN. 2004. Reproduction of the colonial hydroid Obelia geniculata (L., 1758) (Cnidaria, Hydrozoa) in the White Sea. Hydrobiologia. 530/531: 383-388. 